\title{
MASA DEPAN EKONOMI ISLAM: DARI PARADIGMA MENUJU METODOLOGI ${ }^{1}$
}

\author{
Aji Dedi Mulawarman \\ Universitas Brawijaya, Jl. MT. Haryono 165, Malang \\ Email: ajidedim@ub.ac.id
}

\begin{abstract}
Abstrak. Masa Depan Ekonomi Islam: Dari Paradigma Menuju Metodologi. Riset ekonomi Islam saat ini berfokus pada penelitian yang menekankan pada progresivitas dan pengukuran kuantitatif. Implementasi paradigm positivistik/ neoliberal yang tidak memiliki keberpihakan kepada ekonomi rakyat. Diperlukan suatu Pemetaan Konstruktif Ekonomi Islam yang akan mengarahkan riset lebih inward-looking daripada outward-looking. Kajian Non Positivistic dan Ushul Figh dalam Constructive Mapping dilakukan melalui beberapa pendekatan. Pertama, Tarikh, Sirah atau metodologi baru sejarah seperti pendekatan Genealogis. Kedua, pendekatan Social Structure, Tafsir, Ta'wil. Ketiga, Pendekatan Burhani atau Fenomenologis untuk menemukan metafisika masyarakat. Berdasarkan Non-Positivistic dan Ushul Fiqh Approach di atas diperlukan sinergi dengan PositivisticApproach, yaitu Sinergi Emansipasi (Emancipation Approach).
\end{abstract}

\begin{abstract}
The Future of Islamic Economy: From Paradigm to Methodology. Islamic economic research nowadays focuses on progressivity that hinges on quantitative measurement. Positivistic-neoliberal approach does not support peoplebased economy. Constructive Approach on Islamic Economy is needed to direct research to inward-looking perspective rather than outward-looking perspective. Non-positivistic and Ush Fiqih in constructive mapping can be carried out through various approach. First, Tarikh or Sirah or new historical methodologies such as Genealogi. Second, social structure approach, Tafsir and Ta'wil. Third, Burhani approach or phenomenology to discover society metaphysics. Based on non-positivistic and Usul Fiqih approach, a sinergy with positivistic approach is needed, namely Emancipation Sinergy.
\end{abstract}

Kata kunci: Positivistic, Non-positivistic, Constructive Approach on Islamic Economy, Emancipation Synergy

Perkembangan Ekonomi dan Bisnis Islam di Indonesia hari-hari ini memasuki masa keemasan dan kegemilangannya. Bagaimana tidak, bila dilihat dari ukuran-ukuran progresifitas di ranah praktik (seperti menjamurnya perbankan, asuransi, sukuk, gadai, BMT dan lainnya) maupun di dunia akademis (seperti banyaknya pembukaan prodi ekonomis Islam, konferensi, pelatihan, riset dan lainnya), semua mengalami ledakan eksponensial yang menggembirakan. Memang, Ekonomi dan

1 Materi TOT Pemikiran Ekonomi Islam; Prodi Ekis FEB-UB bekerjasama dengan DPN FORDEBI (Dewan Pengurus Nasional Forum Dosen Ekonomi dan Bisnis Islam); Malang 17-18 April 2013
Bisnis Islam sejak kelahirannya mencoba menawarkan alternatif intelektual sampai di tataran praktis yang berseberangan dengan logika Neoliberalisme Ekonomi. Yang perlu dicermati sebenarnya, perkembangan eksponensial di ranah praktis maupun di ranah akademis $^{1}$ lebih "tumbuh subur" terutama di bidang finance, baik di lingkup Internasionalmaupun Indonesia.

2 Dari sisi riset, Muqorrobin (2008) dalam artikelnya mengenai perjalanan ekonomi Islam di dunia modern bahkan memetakan studi yang dilakukan oleh para akademisi ekonomi Islam. Menurutnya, penelitian ekonomi Islam lebih kurang $40 \%$ berkenaan dengan finance dan perbankan atau tidak kurang dari 1800 penelitian selama kurun 1994-

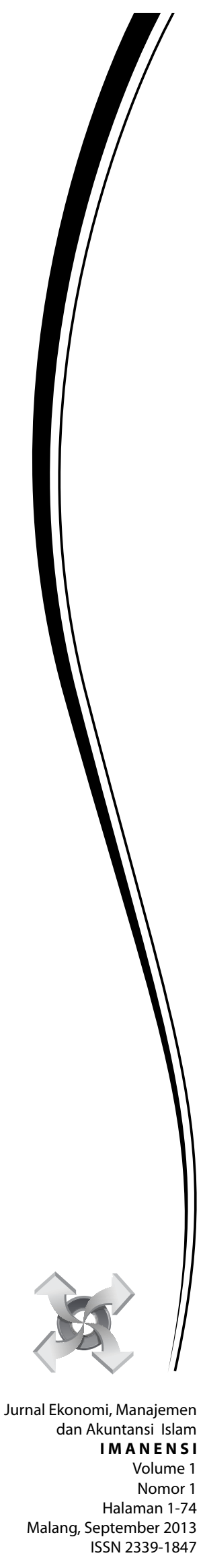


Di lingkup internasional, kepercayaan terhadap praktik Ekonomi Islam tidak dapat dipungkiri telah mencapai puncaknya tahun-tahun ini. World Islamic Banking Competitiveness Report 2011-12 yang disampaikan pada $18^{\text {th }}$ Annual The World Islamic Bank Conference 2011 menyatakan bahwa ekonomi global dan pasar keuangan berada pada titik balik. Pertumbuhan Ekonomi yang cepat di Asia, Timur Tengah, Afrika, Amerika Latin dan Eropa Timur membentuk hampir setengah dari PDB global dan, pada 2010, menyumbangkan $70 \%$ terhadap pertumbuhan global secara keseluruhan. Kecenderungan ini mempercepat perkembangan dramatis selama dua belas bulan terakhir - termasuk Arab Spring, krisis ekonomi di negeri-negeri ber-Zona Euro dan dampak gerakan Occupy Wall Street, memberikan dorongan lebih lanjut pertumbuhan perbankan syariah. Perkiraan industri menunjukkan aset perbankan syariah secara global, akan mencapai $\$ 1,1$ triliun pada 2012 (2010: \$ 826 miliar). Sedangkan menurut UK Islamic Finance Secretariat dalam Islamic Finance 2012 Report menyatakan asset global keuangan syariah telah mencapai $\$ 1,130$ pada tahun 2010 dan diperkirakan sebesar $\$ 1,289$ triliun pada tahun 2011.

Keuangan dan perbankan syariah di Indonesiapun mengalami perkembangan menggembirakan. Penilaian Global Islamic Financial Report (GIFR) tahun 2011, diungkapkan Halim Alamsyah, Deputi Gubernur Bank Indonesia pada Milad ke-8 IAEI, 13 April 2012, Indonesia menduduki urutan keempat negara yang memiliki potensi dan kondusif dalam pengembangan industri keuangan syariah setelah Iran, Malaysia dan Saudi Arabia. Peningkatan menuju global player juga terlihat meningkatnya ranking total aset keuangan syariah dari urutan ke17 pada tahun 2009 menjadi urutan ke-13 pada tahun 2010 dengan nilai aset US $\$ 7,2$ miliar. Total aset keuangan syariah Indonesia pada tahun 2011 diyakini telah melebi-

2005. Penelitian yang banyak di subsector ini, lanjut Muqorrobin, konsisten dengan fakta bahwa praktik perbankan dan financial memang tumbuh pesat, yang kemudian diikuti dengan pertumbuhan monetary market. Kontras sekali dengan perkembangan ekonomi Islam di subsector pasar riil seperti kebijakan fiskal, trade dan commerce, property, sales, dan bahkan pertanian. Hal yang sama juga terjadi pada subsectoretika bisnis, eradikasi kemiskinan, pembangunan ekonomi, ketenagakerjaan, pengembangan sumber daya manusia/insani serta masalah gender. hi US\$20 miliar sehingga rankingnya akan meningkat signifikan. Dengan menggunakan asumsi nilai kurs Rp9.100/US\$, maka nilai aset perbankan syariah akhir tahun 2011 mencapai US\$16,37 miliar, outstanding sukuk (negara dan korporasi) US\$4,41 miliar, asuransi syariah US\$0,97 miliar, reksadana syariah US\$0,61 miliar. Sampai Februari 2012, industri perbankan syariah telah mempunyai jaringan sebanyak 11 Bank Umum Syariah (BUS), 24 Unit Usaha Syariah (UUS), dan 155 BPRS, dengan total jaringan kantor mencapai 2.380 kantor yang tersebar di hampir seluruh penjuru nusantara. Total aset perbankan syariah mencapai Rp149,3 triliun (BUS \& UUS Rp145,6 triliun dan BPRS Rp3,7 triliun) atau tumbuh sebesar $51,1 \%$ (yoy) dari tahun sebelumnya. Industri perbankan syariah menunjukkan akselerasi pertumbuhan tinggi dengan ratarata $40,2 \%$ pertahun dalam lima tahun terakhir (2007-2011), sementara rata-rata pertumbuhan perbankan nasional hanya $16,7 \%$ pertahun.

Tetapi apakah benar bahwa Ekonomi Islam telah menunjukkan kinerja yang sesuai dengan mandat Ketuhanan lewat fiqh, Maqashid Syariah, mengarah pada Mashlaha untuk Ummat?Apakah mungkin memang Ekonomi Islam telah menggiring Ekonomi Kerakyatan menuju Ekonomi "semu" atau menjadi subordinat Neoliberalisme?Pertanyaan lanjutannya kemudian, apakah Perbankan Syariah sudah berpihak pada kepentingan usaha ekonomi rakyat, yang menjadi basis dan orientasi mendasar dari cita-cita kebangsaan kita seperti termaktub dalam pasal 33 UUD 1945?

Berkaitan dengan pertanyaan pertama, beberapa data mengenai hal itu, misalnya Direktur Eksekutif Departemen Perbankan Syariah Bank Indonesia, Edy Setiadi, mengatakan bahwa dari total 51 juta UMKM secara nasional, perbankan syariah baru menyalurkan pembiayaannya kepada 2 juta nasabah UMKM dengan nilai mencapai 124 Trilyun. Tetapi bila kita cermati lebih mendalam, dengan ukuran-ukuran yang ada sampai akhir tahun 2012, fokus pembiayaan perbankan syariah masih berkutat di areal retail (konsumsi), jasa dan perdagangan. Pembiayaan yang terserap pada areal konsumsi sangat tinggi, yaitu berkisar 57,78 Trilyun atau $42 \%$ per September 2012, naik dari tahun ke tahun (sebagai perbandingan 5,66 Trilyun atau $28 \%$ tahun 2006). Pembiayaan untuk kepentingan UKM bila dilihat 
Tabel 1. Pembiayaan Bank Umum Syariah dan UUS berdasarkan Golongan Pembiayaan

\begin{tabular}{lrcrc}
\hline Pembiayaan & \multicolumn{2}{c}{2006} & \multicolumn{2}{c}{ September 2012} \\
\hline UKM & $14,872 \mathrm{~T}$ & $72,74 \%$ & $80,456 \mathrm{~T}$ & $61,72 \%$ \\
Usaha Besar & $5,573 \mathrm{~T}$ & $27,26 \%$ & $49,902 \mathrm{~T}$ & $38,28 \%$ \\
Total & $20,445 \mathrm{~T}$ & $100 \%$ & $130,358 \mathrm{~T}$ & $100 \%$ \\
\hline
\end{tabular}

Sumber: Statistik Perbankan Syariah September 2012 (diolah)

dari jumlah memang naik dari tahun 2006 sebesar $14,9(72,7 \%)$ Trilyun menjadi 80,4 Trilyun $(69,9 \%)$ per September 2012. Tetapi bila dilihat lebih jauh pertumbuhan pembiayaan untuk UKM cenderung menurun dari tahun ke tahun dibanding perkembangan pembiayaan total dari tahun 2006 sebesar 20,4 Trilyun menjadi 130 Trilyun per September 2012. Pertumbuhan signifikan diberikan kepada Usaha Besar yang tahun 2006 hanya 5,6 Trilyun $(27,3 \%)$ dan bertumbuh pesat menjadi 50 Trilyun $(38,3)$.

Berdasarkan penjelasan di atas, sebenarnya Bank Indonesia sebagai pemegang otoritas regulasi dan pengawasan maupun perbankan syariah sebagai pelaku belum dapat melakukan "keberpihakan" melalui "pertumbuhan" dan "angka", terhadap perkembangan ekonomi nasional, ekonomi rakyat, terutama kalangan pengusaha kecil dan menengah, termasuk usaha mikro. BI maupun perbankan syariah belum dapat memacu "prioritas" pertumbuhan pembiayaan kepada UKM dengan tetap memberikan ruang kehati-hatian sekaligus pemberdayaan nyata.

Keberpihakan dan pemberdayaan juga perlu dilakukan pada bentuk pembiayaan sector pertanian dan kehutanan. Berdasarkan data BI selama tahun 2006 sampai September 2012 menunjukkan prioritas pembiayaan masih berada pada jasa, transportasi, dan perdagangan. Perlu diketahui, Indonesia merupakan "gudangnya" petani, bahkan berdasarkan data dari Badan Pusat Statistik (BPS) tahun 2010, sektor pertanian menyumbangkan jumlah angkatan kerja paling besar yaitu 46,7 juta jiwa (44\% dari total angkatan kerja). Bahkan di Indonesia, saat ini masih bergulir Prioritas Nasional dari Kabinet
Indonesia Bersatu II yang ternyata "hanya" menekankan Ketahanan Pangan, bukannya Kemandirian Pangan. Ketahanan Pangan lebih mengedepankan pemenuhan kebutuhan pangan masyarakat secara nasional. Berbeda dengan pendekatan Kemandirian Pangan, di samping menekankan ketersediaan pangan juga berorientasi keberpihakan kepada petani menuju swasembada pangan nasional secara mandiri. Tetapi sayangnya pembelaan terhadap sector pertanian juga belum menjadi prioritas perbankan syariah. Apabila merujuk Statistik Perbankan Syariah yang dikeluarkan Bank Indonesia per September 2012, pembiayaan sector pertanian paling kecil di antara sector-sektor lainnya, yaitu hanya 2,511 Trilyun dari total 130, 357 Trilyun pembiayaan yang dikeluarkan oleh Bank-bank Syariah. Bahkan bila diteliti lebih lanjut, pertumbuhan pembiayaan juga cenderung turun dari tahun ke tahun. Tahun 2006 pembiayaan untuk pertanian masih di kisaran 3,43\% (700 miliar) dan menurun menjadi hanya 1,93\% $(2,511$ Trilyun). Lebih jelasnya lihat tabel 2: Logika hampir sama juga menghampiri pendekatan pembiayaan energi, seperti pertambangan, listrik, gas dan air.

Berdasarkan dua contoh di atas, masih terdapat "prioritas" berorientasi positivisticneoliberal di kalangan perbankan syariah yang belum dapatmemberikan alternatif menyentuh sector riil dan berpihak rakyat kecil, ekonomi rakyat. Bahkan bila merujuk fiqh muamalah dalam Islam, akad-akad yang dikembangkan berkenaan dengan pusatnya, konsep bagi hasil atau profit loss sharing system menjadikan Islam memiliki positioning yang merepresentasikan anti riba. Dari lima jenis hukum akad syariah yang bersi-

Tabel 2. Pembiayaan Bank Umum Syariah dan UUS berdasar Sektor Ekonomi

\begin{tabular}{lllll}
\hline Pembiayaan & 2006 & \multicolumn{3}{c}{ September 2012 } \\
\hline Sektor Pertanian & 700 Miliar & $3,43 \%$ & 2,511 Trilyun & $1,93 \%$ \\
Total Pembiayaan & 20,445 Trilyun & $100 \%$ & 130,357 Trilyun & $100 \%$ \\
\hline \multicolumn{2}{l}{ Sumber: Statistik Perbankan Syariah September 2012 (diolah) }
\end{tabular}


Tabel 3. Komposisi Pembiayaan Bank Umum Syariah dan UUS

\begin{tabular}{lcccccrcr}
\hline Akad & \multicolumn{1}{c}{2006} & \multicolumn{2}{c}{2009} & & 2011 & \multicolumn{3}{c}{ Sept 2012 } \\
\hline Mudharabah & $4,062 \mathrm{~T}$ & $19,87 \%$ & $6,597 \mathrm{~T}$ & $14,07 \%$ & $10,229 \mathrm{~T}$ & $9,96 \%$ & $11,359 \mathrm{~T}$ & $8,71 \%$ \\
Musyarakah & $2,335 \mathrm{~T}$ & $11,42 \%$ & $10,412 \mathrm{~T}$ & $22,21 \%$ & $18,960 \mathrm{~T}$ & $18,47 \%$ & $24,481 \mathrm{~T}$ & $18,78 \%$ \\
Murabahah & $12,624 \mathrm{~T}$ & $61,75 \%$ & $26,321 \mathrm{~T}$ & $56,14 \%$ & $56,365 \mathrm{~T}$ & $54,92 \%$ & $77,153 \mathrm{~T}$ & $59,19 \%$ \\
Total & $20,444 \mathrm{~T}$ & $100 \%$ & $46,887 \mathrm{~T}$ & $100 \%$ & $102,656 \mathrm{~T}$ & $100 \%$ & $130,357 \mathrm{~T}$ & $100 \%$ \\
\hline
\end{tabular}

Sumber: Statistik Perbankan Syariah September 2012 (diolah)

fat bagi hasil yakni mudharabah, musyarakah, muzara'ah, musaqah, mukhabarah, tiga diantaranya menekankan akad pertanian. Akad perdagangan hanya mudharabah dan musyarakah, sedangkan muzara'ah, musaqah dan mukhabarah adalah akad pertanian. MUI, BI, pemerintah dan para akademisi harus mulai memikirkan model, aplikasi dan teknik pro rakyat berkenaan dengan tiga akad tersebut, agar dapat menjadi andalan pembiayaan. Pertanian seperti apa, juga harus menjadi amatan serius, pertanian pro rakyat atau pertanian pro pengusaha besar. Apabila kemudian perbankan syariah menggeser pada pembiayaan pertanian tetapi berharap "aman" dan "berteman" hanya dengan perusahaan pertanian berlogika agribisnis, yaitu pertanian estat berskala besar yang dikendalikan perusahaan multinasional dengan meletakkan petani sebagai subordinat tanpa kekuatan bargaining, maka makin tersudutlah pertanian nasional kita, makin meranalah petani.

Pertanyaan kedua, selain keberpihakan, apakah perbankan syariah juga sudah berhasil menggeser orientasi yang selama ini banyak dipertanyakan banyak pihak yang memiliki positioning berbeda dengan kapitalisme dan neoliberalisme?Seperti diketahui, ciri utama mengapa keuangan syariah menjadi symbol anti riba adalah antitesis dari kredit menjadi pembiayaan berorientasi bagi hasil (profit loss sharing system). Apakah perbankan syariah telah mengarah pada pemberdayaan berorientasi bagi hasil?Data menunjukkan bahwa komposisi pembiayaan yang diberikan Bank Umum Syariah dan UUS (Unit Usaha Syariah) masih mengarah pada akad murabahah. Murabahah bukanlah bagi hasil, tetapi prinsip akad jual beli yang sangat "dekat" dengan prinsip riba. Contoh konkrit, murabahah ditengarai beberapa akademisi dan praktisi belum berwajah Islami karena dibayangi aktivitas riba di lapangan. Data Statistik Perbankan Syari'ah Januari 2007 menunjukkan komposisi murabahah per Desember 2006 mencapai $61,75 \%$ dan per Januari $61,76 \%(12,487$ triliun rupiah). Kecenderungan tahun 2007 memang mengalami penurunan daripada komposisi per desember 2005 yang mencapai $62,3 \%$. Tetapi bila dilihat dari nilai rupiah terlihat kenaikan dari 2005, yaitu 9,487 triliun rupiah, menjadi 12,624 triliun rupiah pada 2006. Meskipun arah menuju penerapan sistem mudharabah maupun musharakah juga mulai banyak diinginkan. Hal itu terlihat dari jumlah pembiayaan mudharabah 2005 mencapai 3,123 triliun rupiah dan 2006 menjadi 4,062 triliun rupiah. Tetapi bila dilihat dari prosentase, pembiayaan mudharabah mengalami penurunan dari 2005 sebesar $20,5 \%$ menjadi $19,87 \%$ pada 2006 dan turun kembali pada Januari 2007 yaitu sebesar $19,82 \%$. Jumlah pembiayaan musharakah tahun 2005 mencapai 1,898 triliun rupiah menjadi 2,335 triliun rupiah pada 2006. Bila dilihat berdasarkan prosentase, pembiayaan musharakah mengalami penurunan dari $12,5 \%$ pada 2005 menjadi $11,42 \%$ pada 2006 . Ternyata perkembangan terbaru juga masih memberikan logika yang sama.

Tahun 2006 akad murabahah berada pada posisi $61,75 \%$ dan bergerak menurun pada tahun 2011 sebesar 54,91\%. Tetapi sayangnya, per September 2012 meningkat kembali menjadi 59,19\%. Sedangkan akad mudharabah dan musyarakah sebagai representasi dari prinsip bagi hasil malah menunjukkan kinerja makin menurun. Mudharabah misalnya, tahun 2006 berada pada posisi $19,87 \%$ dan terus mengalami penurunan pada tahun 2012 (September), yaitu $8,71 \%$. Musyarakah pada tahun 2006 mencapai $11,42 \%$ dan meningkat pesat $22,21 \%$ tahun 2009, setelah itu mengalami penurunan tiap tahun menjadi hanya $18,78 \%$ per September 2012.

Berdasarkan data di atas, Perbankan Syariah masih beradapada mindset yang hanya berorientasi pertumbuhan dan keinginan untuk meraup laba setinggi-tingginya. Perbankan Syariah belum dapat-dengan kepercayaan yang makin meningkat di kalangan masyarakat-mengarahkan kepentingannya menjadi pintu penyelamatan ekonomi masyarakat, ekonomi Islam. Pertanyaannya kemudian adalah mengapa hal itu dapat terjadi? Seperti akan dijelaskan di bawah, 
masalahnya bukan hanya pada data-data teknis perkembangan ekonomi Islam seperti dijelaskan di atas, tetapi lebih dari itu, terdapat masalah mendasar lain yang menyelimuti, yaitu permasalahan paradigmatic dunia Ekonomi Islam, yang nantinya akan mengarah pada model metodologi sampai teknis riset.

\section{POSITIVISTIC APPROACH DAN ISLAMISA- SI ILMU}

Mulawarman (2010)melihat bahwa selama ini yang dilakukan oleh para pengamat dan predictor ekonomi Islam/Syariah mungkin belum lengkap, karena menggunakan Positivistic Approach, terlalu berorientasi pendekatan matematis dan kuantitatif, serta outward looking. Baik perkembangan Internasional maupun Regional tersebut biasanya menggunakan model pengukuran yang mirip dengan perhitungan-perhitungan dan asumsi-asumi dasar Ekonomi konvensional, seperti penghitungan indeks, (jumlah bank syariah, jumlah lembaga keuangan nonbank syariah, maupun ukuran aset keuangan syariah yang memiliki bobot terbesar, dan lainnya). Berdasarkan ukuran-ukuran kuantitatif seperti itu dapat dilihat betapa laju ekspansi kelembagaan dan akselerasi pertumbuhan aset perbankan syariah yang sangat tinggi, ditambah dengan volume penerbitan sukuk yang terus meningkat. Berdasarkan logika yang sama, dapat kita lihat misalnya laporan-laporan penuh angka yang menakjubkan dan membuat kita terkesima dengan perkembangan perbankan syariah seperti dilansir tiap bulan oleh Bank Indonesia. Sehingga lupa dengan "kenyataan" ekonomi Islam berada di "bumi" Indonesia yang mayoritas petani dan UKM (inward looking). Sesuai kaidah yang dipakai, melihat perkembangan ekonomi Indonesia termasuk ekonomi Islam di Indonesia biasanya lebih familiar bila masuk dalam kerangka positivisme.

Positivistic Approach mengedepankan model: to explain and to predict. Perkembangan ekonomi Islam yang dipakai Positivistic Approachsebagai tolok ukur seperti desain blue print "top-down", prospek-kendala kronologis, struktural kelembagaan, pertumbuhan linier, dan lebih banyak pendekatan proyeksi statistik. Hal ini sesuai dengan alur berpikir positivistik (atau dapat dikatakan sebagai penegas atas logika positivisme dalam teori ekonomi) Milton Friedman (1953/1966), Samuelson, Hutchison dan ekonom-ekonom mutakhir saat belakangan. Sebagaimana dituliskan dalam artikel fenomenal Friedman yaitu The Methodology of Positive Economics tujuan utama dari positive science adalah mengembangkan teori atau hipotesis secara empiris, matematis, materialistic, melalui kekuatan explanasi validitas dan makna prediksi mengenai fenomena terobservasi. Pengembangan teori dan hipotesis positivistic bagi Friedman tak dapat lepas dari logika ekonomi dasar atau normative economics itu sendiri, sepertiprice of products atau faktorfaktor produksi sertainterelasi antara supply dan demand di market berkenaan dengan kebermanfaatan (utility) dan kegunaan (usefulness) serta kelangkaan (scarcity) berorientasi pada self-interestbehavior dan berujung pada pembentukan permodelan (abstract model). Pendekatan positivistic juga berlaku pada manajemen (FW Taylor dengan Principles of Scientific Management) maupun akuntansi (Positive Accounting Theory yang dilansir secara formal oleh Watts dan Zimmerman). Baik di domain ekonomi, manajemen/bisnis, maupun akuntansi, positivisme sebenarnya merupakan gerakan empiricism untuk melegitimasi sifat dasar kemanusiaan Barat, yaituSelf Interest.

Banyak kritik terhadap PositivisticApproach oleh para ekonom Barat sendiri (misal Leontif 1982; Ormerod 1994; Lawson 2002 dan banyak lainnya). Kritik Leontif (1982) mengatakan bahwa jurnal-jurnal ekonomi didominasi dan telah terdesain rumus matematika sampai permodelan dan masuk lebih dalam untuk mengeksplore ekonomi lewat angka-angka untuk memotret beroperasinya system ekonomi yang nyata. Menurut Lawson (2002; 5-7) merupakan kesalahan pilihan metode ilmu ekonomi dalam melihat realitas, ekonomi yang telah terjebak dalam konsep dan rumusan ekonometrik. Tetapi bagi Lawson (2002) ilmu ekonomi tidak hanya terjebak pada kesalahan metode saja, tetapi juga terjebak dalam kesalahan inkonsistensi pada level teori sosial dan metodologis. Level teori sosial berkenaan dengan aliran ekonomi mainstream yang menggunakan ekonometrik sebagai alat untuk memperjelas pilihan (choice) manusia yang deterministic dan individualistic, berujung pada sinyal "take the form of market prices". Sedangkan pada level metodologis, realitas ekonomi hanya berkenaan masalah pilihan matematis (ekonometrik) atau tidak, tetapi lebih pada penggunaan metode yang jelas dipengaruhi oleh masalah filosofi, belief system 
dan mentalitas. Kritik epistemologis sebenarnya juga disampaikan Choudhury (2005). Beliau melihat bahwa Ekonomi Islam saat ini masih mengidap penyakit akut ekonomi konvensional dan terjebak "afeigned kind of neoliberal and neoclassical doctrinaire". Usulan melakukan reorientasi epistemologis ekonomi Islam dengan melakukan induksi Tawhid secara tegas. Meskipun demikian, Choudhury (2005) tetap menyepakati digunakannya metodologi/metode positivistic.

Dua mencoba memahami ekonomi dalam perspektif yang lebih meta paradigmatik, menarik semua simpul ekonomi pada ukuran yang sama, yaitu kesejahteraan dan keadilan masyarakat sebagai puncak kepentingan ekonomi. Michael Dua menyimpulkan bahwa bila ekonomi di-filsafati, maka yang menjadi pemikiran semua gerbong ekonomi, baik aliran kapitalis, sosialis, ekonomi sosial atau ekonomi lingkungan, adalah dua kata magis, yaitu keadilan dan kesejahteraan. Dua kata magis ini memerlukan apa yang dinamakannya sebagai Etika Berekonomi, Berekonomi dengan Hati. Sayangnya apa yang dilakukan oleh Michael Dua nampaknya masih berputar pada sekularisasi ekonomi dan juga bukan melakukan perubahan signifikan atas ekonomi yang ada. Yang dilakukannya hanyalah melakukan pembacaan ulang atas dogma-dogma ekonomi yang dominan dan dengan melihat kembali pada akar pikiran masing-masing dogma, Michael Dua mencoba menarik kata kunci yang ada di seluruh dogma, yaitu keadilan dan kesejahteraan yang berhati nurani.

Pikiran Dua (2008) sepertinya mirip dengan apa yang telah digagas oleh Sen (1987). Bila dilihat dari perspektif yang lebih teoritis, menarik apa yang ditulis oleh O'hara (2002) berkenaan dengan bagaimana mensinergikan pemikiran ekonomi Marx, Veblen, Keynes dan Schumpeter dengan apa yang dinamakannya sebagai Critical Economics Systems Approach. Tetapi sekali lagi, apa yang dibincangkan oleh O'hara adalah bagaimana menyelesaikan masalah ekonomi dalam koridor yang sama, yaitu bagaimana menyelesaikan masalah kesejahteraan dan keadilan dalam sistem ekonomi, proses sosioekonomi dan pendekatan distribusi kekayaan dalam koridor multiple capital (diri-sosial-alam).

Pilihan lain dari melakukan telaah filsafat atas ekonomi, juga telah banyak dilakukan. Kita lihat misalnya yang dilakukan
Capra atau Zohar dan Marshall. Bagi mereka pilihan filsafat ekonomi yang melampaui filsafat menjadi penting, yaitu melakukan spiritualisasi ekonomi. Capra misalnya, dari berbagai bukunya yang digulirkan seperti The Tao of Physics, TheTurning Point, The Web Life atau yang terbaru The Hidden Connection, semua yang berkenaanekonomi dihubungkan dengan karakter utama spiritualitas organis postpatriarkal. Ekonomi yang harus dikedepankan adalah ekonomi yang memiliki spirit organis dalam bingkai alam semesta. Lebih mudah lagi, spiritualisasi ekonomi harus mengedepankan sinergi organis untuk keseimbangan kepentingan materi-batin-spiritual dalam diri-sosial-alam. Pikiran ini juga mirip dengan apa yang dilakukan oleh Zohar dan Marshall dalam bukunya Spiritual Capital. Logika Zohar dan Marshall, melihat bahwa yang dikejar oleh setiap manusia sebenarnya adalah satu kata kunci, yaitu Capital. Bagi mereka yang perlu dilakukan adalah melakukan "beyond"capital, yaitu capital bernilai materi, sosial sekaligus spiritual untuk menangkap sinyalkepentingan diri-sosial-alam.

Sebenarnya pemikiran yang lebih menarik adalah apa yang dilakukan oleh Schumacher, dengan simbol Small is Beautifull yang kemudian difilsafati dengan $A$ Guide forthe Perplexed (1981). Buku relatif lama ini sebenarnya telah melakukan loncatan sejarahnyasendiri, yang mencoba menarik ekonomi dalam konteks filsafat dengam memberikan model pencerahan baru, keluar dari dominasi ekonomi mainstream. Pikiran Schumacher sebenarnya bisa dijadikan model pikiran baru dalam ekonomi yang memiliki "ruh" Ketuhanan. Tetapi memang masalahnya adalah Schumacher tidak bisa melakukan penurunan konteks normatifnya menjadi lebih membumi dan aplikatif.

Di Indonesia sendiri, pemikiran menuju "ekonomi baru" banyak bertebaran dan tidak kalah menariknya. Seperti aliran ekonomi kerakyatan Hatta dan varian-variannya, seperti Mubyarto, Sritua Arif, Sarbini, dan lainnya. Aliran Soedjatmoko memang tidak begitu membumi dan tidak pula begitu banyak dilirik kecuali sering hanya menjadi inspirasi "nakal" ekonomi baru. Berbeda dengan aliran Hatta dengan Ekonomi Kerakyatannya, yang sebenarnya telah termanifestasi dalam sendi-sendi dasar kenegaraan kita, pasal 33 UUD 1945. Masalahnya pula ekonomi kerakyatan hanyalah tinggal "simbol", baik 
simbol kenegaraan maupun simbol marginal di bawah Departemen Koperasi dan Usaha Mikro, Kecil dan Menengah. Yang kita jalani sekarang ini, Indonesia telah memasuki era liberalisasi pasal 33 UUD 1945 dalam bentuk ekonominya sekarang ini. Simbolisasi ini bukan hanya dalam bentuk kenegaraan dan marginalisasi Departemen saja, bahkan di bidang pendidikan yang mencetak para ekonom-pun juga telah terjadi simbolisasi. Bila kita lihat seluruh mata kuliah yang ada di Fakultas Ekonomi, dominasi ekonomi kapitalis dan sekarang berbalut wajah baru neoliberalisme telah mengakar kuat.

Dari penjelasan panjang lebar dari penggunaan positivistic ekonomi maupun alternatif-alternatif ekonomi lainnya terdapat satu kesamaan, yaitu masalah kesejahteraan. Demikian pula yang dilakukan oleh Ekonomi Islam dalam perspektif Positivistik. Kalaupun ada yang namanya tujuan kesejahteraan itupun kelihatannya tidak berbeda dengan ekonomi konvensional. Perbedaan hanya ada pada aras ontologisnya, yaitu bahwa tujuan akhir manusia adalah untuk Allah (Tawhid). Tetapi ketika turun pada kerangka metodologis, metode maupun system, meski logika Islam dan Barat beda, tetapi, sekali lagi ketika pikiran positivistic masuk dalam kerangka berpikir Islam, maka yang terjadi adalah orientasi yang lebih pragmatis. Orientasi pragmatis memang melekat kuat di araspositivistic, yaitu ber-Tawhid tetapi tetap mengidap penyakit "kesejahteraan yang lebih dekat pada kepentingan pertumbuhan, linieritas serta mekanis". Apabila dilihat dari filosofi ekonomi konvensional, Pemikiran Ekonomi Kapitalis, Sosialis, Lingkungan atau Ekonomi Baru selalu mendiskusikan alternatif dari dua kata magis Kesejahteraan dan Keadilan menuju Ekonomi Berhati Nurani (Michael Dua 2008). Tidak ada di dunia ini yang mengatakan ekonomi itu tidak bertujuan pada kesejahteraan. Dan itu pula yang kemudian dikritik bahwa ekonomi kesejahteraan Barat hanyalah kesejahteraan bersifat pertumbuhan dan linieritas serta mekanistis. Pemikiran Ekonomi Baru ala Capra atau Danah Zohar dan Ian Marshall kemudian mendekati Ekonomi dalam koridor Spiritualitas yang memberi jiwa bagi kepentingan diri-sosial-alam.

Ekonomi Islam sendiri sebenarnya secara ontologis telah menempatkan Tawhid sebagai dasar dari peletakan ontologis yang jelas sekali berbeda dengan Ekonomi Konvensional. Perdebatan apakah Ekonomi per- lu di-Islam-kan kembali atau tidak biasanya mengarah pada proyek Islamisasi Pengetahuan. Meski Penulis sendiri tidak begitu sepakat dengan apa yang disebut dengan Islamisasi Pengetahuan. Penulis tetap menyepakati dan menggunakan level ontologis ekonomi Islam yang menggunakan Tawhid sebagai landasan utama Ekonomi Islam. Sejak pertengahan 70'an isu mengenai Islamisasi pengetahuan telah menjadi agenda intelektual dan berupaya melakukan revolusi epistemologi. Bila dirunut dari awal, Islamisasi Ilmu berawal dari keresahan para intelektual awal yang menurut Al-Faruqi disebut sebagai "guru paling terkemuka" yaitu Muhammad Abduh dan Muhammad Iqbal. Terutama Iqbal dalam bukunya yang sangat revolusioner, berjudul "The Reconstruction of Religious Thought in Islam" yang merupakan kumpulan ceramah-ceramah filosofis beliau. (semoga Allah selalu memberkati dan memberikan tempat yang sempurna di sisi-Nya). Menurut Wan Daud (2003, 389) pikiranpikiran filosofis Iqbal merupakan pikiran yang mendahului jamannya, dan oleh Fazlur Rahman disebut Tasawuf Positif. Pusat Islamisasi ini adalah sintesa kreatif ilmu-ilmu Islam tradisional dan disiplin-disiplin ilmu Modern. Sintesa ini diharapkan Al-Faruqi memberikan solusi bagi permasalahan masyarakat muslim, yang digulirkan menjadi bentuk buku-buku daras dan kurikulum pendidikan yang sesuai dengan nilai-nilai Islam dan realitas masyarakat muslim. Langkah-langkah konkrit Al-Faruqi bukanlah sebuah model yang selesai. Banyak pengembangan dan kritik disampaikan, misalnya pengembangan yang dilakukan oleh International Institute of Islamic Thought. Atau bahkan kritik yang disampaikan oleh Sardar (1987), Al-Attas dan banyak lagi setelahnya di Indonesia seperti Mahzar (2005) atau Kuntowijoyo (2004), dan lain-lain. ${ }^{3}$

Terlepas dari diskursus, kritik dan berbagai alternatif yang mengemuka berkenaan Islamisasi Ilmu, tetapi diakui sejak itulah

3 Kritik Sardar (1987) atas proyek dan langkah Islamisasi Faruqi, adalah pada pengabaian realitas epistemologis Barat yang membangun dunia modern saat ini. Proyek Islamisasi Faruqi seakan tidak melihat kekuatan epistemologi Barat yang mendominasi seluruh lini pengetahuan yang telah berkembang saat ini. Sardar menegaskan bahwa yang paling penting sebelum dilakukan proses praktis seperti yang dilakukan dalam Islamisasi Faruqi adalah melakukan perubahan epistemologis Barat terlebih dahulu (Sardar 1987, 85-106). Kritik AlAttas terhadap Islamisasi yang dilakukan Faruqi, 
Ilmu Pengetahuan dan Ekonomi mendapat perhatian luar biasa dari para sarjana dan ilmuwan Muslim. Buku hasil pemikiranpemikiran alternatif ekonomi Islam dengan Tawhid sebagai landasan utama, jawaban atas kegalauan epistemologis ekonomi konvensional misalnya telah dilakukan MN. Siddiqi, Anas Zarqa, Monzer Kahf, M. Akram Khan, Muhammad Ariff, Khursid Ahmad, dan lain-lain di buku "babon", salah satunya berjudul Readings in the Concept and Methodology of IslamicEconomics (Ghazali dan Omar 1989) yang jadi rujukan hampir setiap pemikir Ekonomi Islam. Tetapi sekali lagi, ada pemakluman atas dominasi penggunaan positivisme dalam Ekonomi Islam, terutama ketika dijalankan pada aspek metodologis maupun metodenya. Pemikiran dan pemakluman atas "dominasi Positivisme" dalam Ekonomi Islam juga masih terpaparkan padaThe $7^{\text {th }}$ International Conference in Islamic Economics yang diadakan di King Abdul AzizUniversity tahun 2008.

\section{POSITIONING MA'RIFAT EKONOMI}

Apakah pengembangan seperti itu sudah cukup? Apakah pendekatan Positivisme Perkembangan sudah cukup tepat untuk melihat konstruksi Ekonomi Islam ke depan? Atau penggunaan ekonomi alternatif dapat digunakan untuk melihat konstruksi Ekonomi Islam ke depan? Toh tetap saja diskursus untuk perbaikan Ekonomi Islam ke depan memang tidak menutup kemungkinan adanya pengembangan lebih lanjut diskursus keilmuan (baik itu disarankan dalam diskursus Islamisasi Ilmu, Pengilmuan Islam, atau Neo-Modernime Islam atau lainnya) daripada sekedar hanya meletakkan positivime sebagai dasar paling scientific.

seharusnya hanyalah pada Islamisasi ilmu pengetahuan kontemporer saja, dan tidak melakukan rekonstruksi atas ilmu - yang disebutnya - Turath Islamyy. Dan lebih jauh lagi proses Islamisasi harus melakukan dua langkah utama, yaitu proses verifikasi dan proses penyerapan yang harus memiliki batasan, terutama proses sintesis seperti yang merupakan pusat dari Islamisasi Faruqi, yaitu sintesa dapat dilakukan ketika konsep-konsep Barat telah disaring dan direduksi unsur-unsurnya. Yang paling penting, lanjut Al-Attas, Islamisasi Al Faruqi mengecilkan peran tassawuf. Bagi Al-Attas, tassawuf adalah cara yang harus pula dilakukan untuk menyelamatkan manusia dari cengkeraman empirisme, pragmatisme, materialisme dan rasionalisme sempit yang merupakan sumber utama sains modern. Masuknya konsep tassawuf menurut Al-Attas akan memberikan arah yang benar pada kesatuan akal, jiwa, intuisi dan spiritualitas dalam proses Islamisasi (Hashim 2005).
Bagi penulis, ada yang lebih urgen dari sekedar menderivasikan Ekonomi Islam secara positivistik seperti itu. Di sini penulis menamakan Pemetaan Konstruktif Ekonomi Islam (ConstructiveApproach on Islamic Economy).

Makrifat Ekonomi tidak ingin terjebak pada pragmatisme ekonomi maupun adopsi ekonomi tanpa pemikiran mendalam dan substansial. Seperti kita ketahui Ekonomi Islam Kontemporer saat ini memang masih banyak dan terdominasi oleh keuangan dan perbankan Islam. Ekonomi Islam kontemporer saat ini dapat dikerangkakan dalam dua garis utama, berkenaan dengan studi akademis dan arena praksis. Studi akademis selalu berasumsi mengenai kedudukan Islam berhadapan dengan dua kutub ideologi lainnya, kapitalisme dan sosialisme. Akademisi biasanya meletakkan Ekonomi Islam sebagai implementasi figh muamalah yang memiliki tujuan syari'ah, yaitu mashlaha untuk ummat, keadilan dan kesejahteraan. Atas dasar kedudukan tujuan syari'ah tersebut kemudian para akademisi terjebak pada perdebatan apakah ekonomi Islam berbeda, menjadi titik tengah atau melakukan akomodasi atas ideologi kapitalisme atau sosialisme. Arena praksis di sisi lain mencoba merealisasikan konsep fiqhmuamalah akomodatif terhadap sistem ekonomi yang berkembang saat ini. Hasilnya adalahmelakukan modifikasi sistem keuangan, perbankan, asuransi, pemasaran, manajemen dari perspektif Barat. Menjadi maklum ketika hari-hari ini ekonomi Islam banyak bersentuhan dengan pasar saham, sistem pembiayaan (musyarakah, murabahah, atau lainnya), serta lebih mengutamakan aspek penguatan makro ekonomi. Meskipun dalam perjalanannya sistem serta lembaga keuangan Islam masih diliputi kontroversi pemikiran di dunia Islam sendiri maupun perbedaan yang menyolok dengan sistem serta lembaga keuangan konvensional. Perbankan Islam terkait penyelesaian riba (musyarakah/mudharabah dan murabahah), sedangkan pasar modal pada maisir dan gharar.

Makrifat ekonomi tidak lagi mencoba untuk melakukan deklarasi ekonomi baru, atau melakukan penggeseran paradigmatik normatif. Makrifat Ekonomi lebih dilakukan untuk mengajak kita semua melakukan refleksi menuju Cahaya Ketuhanan. Artinya, yang dilakukan di sini adalah mencoba melakukan penyegaran pikiran berekonomi kita, atau katakanlah penyucian ekonomi, tazkiyah ekonomi menuju ekonomi yang 


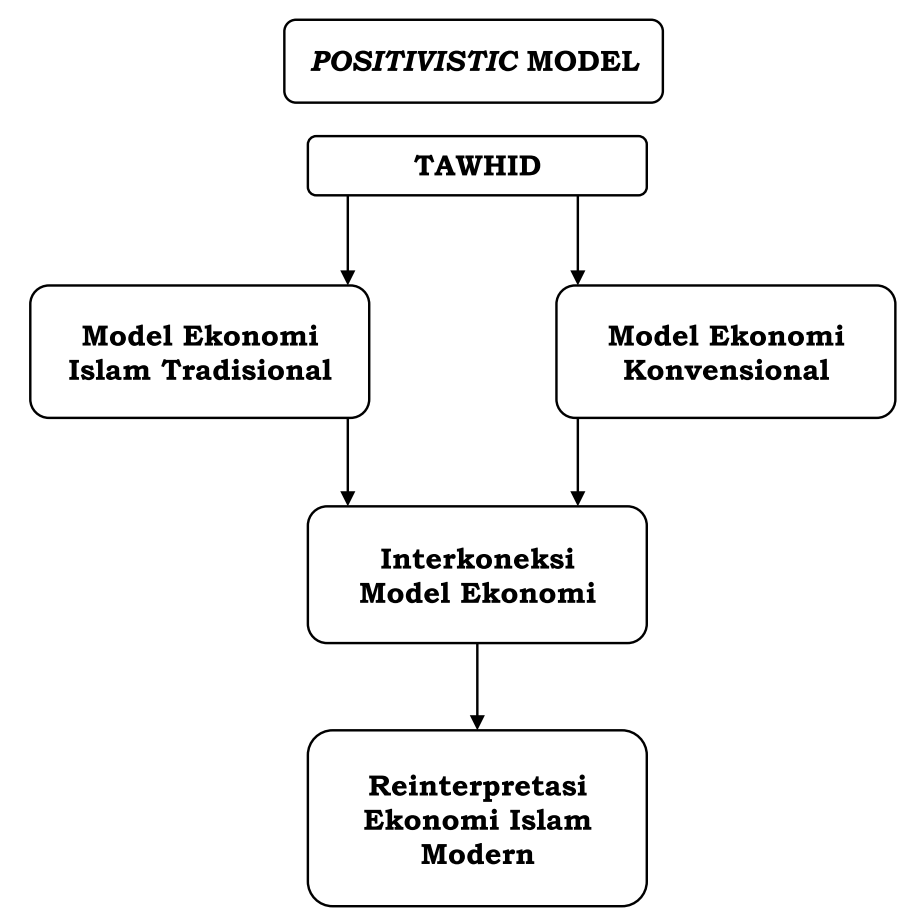

Gambar 1. Positivistic Model dalam Ekonomi Islam

lebih bermanfaat bagi religiusitas diri kita, realitas sosial kita, realitas alam semesta Indonesia kita yang memang masih terakomodasi dalam nilai-nilai religiusitas khas Indonesia. Nilai-nilai religiusitas khas Indonesia dirasakan penting bagi pemikiran ekonomi kita, karena seperti telah dijelaskan di atas, kurikulum nasional kita sebenarnya masih mengidap pseudo-secularism. Mencoba melakukan tazkiyah ekonomi adalah bentuk penyucian ekonomi kita yang masih mengidap penyakit akut, yaitu sekularisasi ekonomi, lepasnya ekonomi dari nilai-nilai religius khas Indonesia, dan lepasnya ekonomi dari nilai-nilai budaya local. Yang diinginkan dalam makrifat ekonomi berdasarkan pada konsep Tazkiyah, adalah menggugah pemikiran ekonomi kita menuju fitrahnya, fitrah diri-sosial-alam yang lebih dalam, fitrah spiritualitas yang lebih dalam, fitrah materi-batin-spiritualitas yang lebih dalam, yaitu Fitrah Religiusitas Lokalitas Indonesia. Bila ditarik lebih jauh lagi, fitrah religiusitas lokalitas Indonesia masih didominasi alam pikiran Islam. Maka yang lebih natural sebenarnya adalah memaknai fitrah dari akar religiusitas dalamnya, yaitu Islam. Ekonomi Islam semestinya tidak hanya mendekatkan kepentingan keadilan dan kesejahteraan atau spiritualitas general an sich, tetapi perlu Beyond. Karena prinsip Islam adalah Fitrah Kemanusiaan dari Fitrah Ketuhanan.
Ekonomi Islam perlu kembali ke fitrahkemanusiaannya, fitrah alam semesta, Fitrah Ketuhanan, Kesatuan Fitrah Kemerdekaan (fungsi khalifatullah fil ardh) sekaligus Kesucian (fungsi abd' Allah). Kesatuan Fitrah nampak pada Sirah Rasul mengedepankan keseimbangan intermediasi-produksi-retail berbasis mikro ekonomi yang mengendalikan makro ekonomi. Implementasinya adalah Trilogi Fitrah,Ma'isyah-Rizq-Maal untuk mencapai Barakah(Mulawarman 2010).

\section{AGENDA MAKRIFAT EKONOMI ISLAM MELALUI TAZKIYAH}

Ma'rifat Ekonomi Islam tidak hanya melakukan pendekatan Positivistic Approach. Positivistic Approach melakukan interkoneksi ekonomi konvensional dengan ekonomi Islamkemudian dilakukan reinterpretasi berdasarkan landasan normative Islam, yaitu Tawhid. Pandangan positivistic di dunia Ekonomi Islam, saya kira salah satunya muncul setelah mendapat penegasan keinginan Arif (1987) untuk memaparkan Islamisasi Pengetahuan ala Faruqi yang masih terlalu luas. Islamisasi Pengetahuan di ranah Ekonomi disebut Arif sebagai prosedur Stratifikasi dan Idealisasi teknis yang mengacu logika ilmu alam (terutama prosedur stratifikasi Enstein). Pendekatan positivistic model sangat top-down dan tidak membumi. Ma'rifat Ekonomi Islam menggunak- 


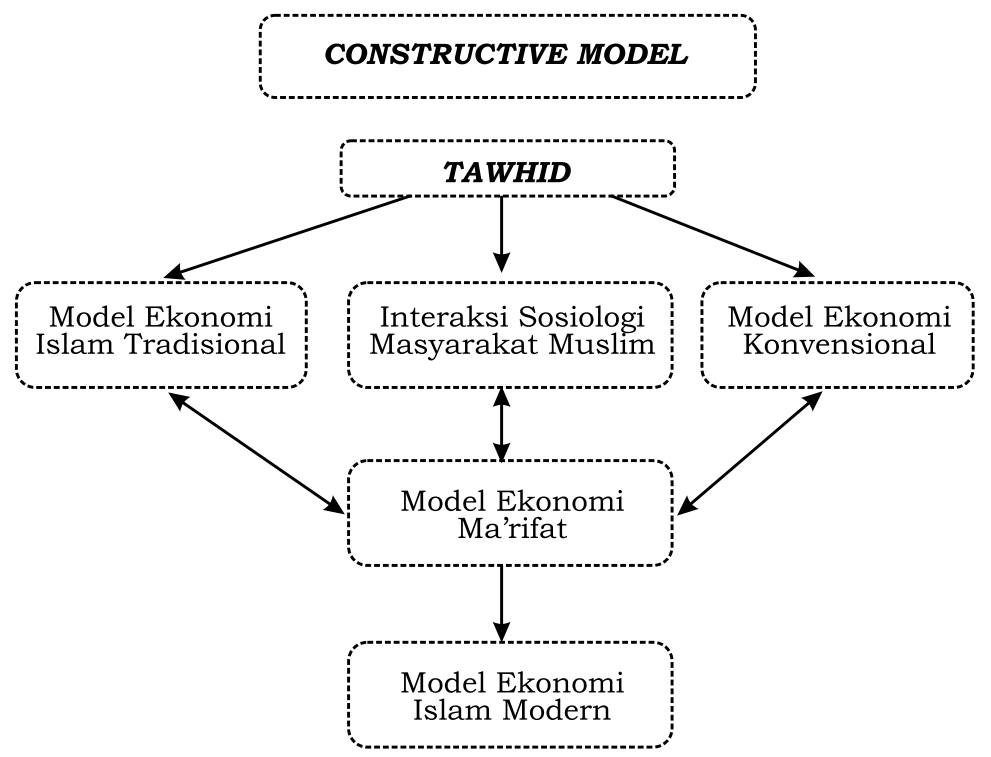

\section{Gambar 2. Constructive Mapping}

an Constructive Approach.Constructive Approachmelakukan integrasi tiga komponen, yaitu model ekonomi Islam tradisional, model ekonomi konvensional disertai dengan pendekatan empiris interaksi sosiologis masyarakat Muslim yang bersifat bottom-up sekaligus top-down. Berdasarkan integrasi tiga komponen tersebut dilakukan reinterpretasi ekonomi Islam berdasarkan landasan normative Islam, yaitu Tawhid.

Desain blue print dan positioning Ekonomi Islam saat ini (source dari PositivisticApproach) memang tidak serta merta ditolak dan dihapus. Desain yang "positivistic" seperti itu"dan sudah ada perlu digunakan dan tetap dijadikan salah satu pijakan. Tetapi itu hanyalah salah satu dari desain ekonomi Islam yang katakanlah di sini disebut Constructive Approach. Dalam Constructive Approach, disamping melakukan(1) Positivistic Approach, diperlukan pula kajian(2) Non-Positivistic seperti kajian socialstructures,fenomenologis dan antropologis, genealogis, serta (3) Pendekatan Ushul-Fiqh seperti tafsir, ta'wil, sirah, tarikh, burhani, urf, qiyas, ijma' dan lainnya bagi ekonomi Islam ${ }^{4}$. Sinergi diperlukan untuk titik temu ide dan metafisika dalam bentuk aksi "New Blue Print".

Meskipun perlu ditegaskan di sini, bah-

4 Sebagai perbandingan dapat dilihat artikel dari Furqani dan Haneef (2011) mengenai pendekatan metodologi Ekonomi Islam yang dapat dipaparkan melalui 3 model, (1) ushul figh; (2) pluralism Islam dan Barat; (3) positive economics. Sebagai perbandingan sangat menarik tulisan Loui Safy wa masing-masing pendekatan yang bersumber dari adaptasi maupun adopsi pendekatan paradigmatic atas basis keilmuan pasti memiliki resiko terbawanya "values" yang melekat di dalamnya. Seperti dijelaskan di Pendahuluan, pendekatan positivistic ketika tidak dilakukan "filter" dengan nilai-nilai Islam, maka yang terjadi adalah prioritas, logika dan kepentingan "values" dalam positivistic approach akan terbawa, data statistik BI hanya menjadi dasar pertumbuhan perusahaan-perusahaan "finance" syariah dan sekaligus menegasikan kepentingan lokalitas, keberpihakan dan prisma kerakyatan yang juga sebenarnya ada dalam tradisi Islam tapi tidak dalam tradisi Barat Modern Positivistik (self-interest). Artinya pula, mengembangkan model katakanlah turunan paradigma dalam bentuk metodologi-metodologi Non-Positivistic Approach juga pasti "mengidap values" dimana metodologi dikembangkan.

Islam sendiri telah memiliki kearifan dan filter Tawhidic yang luar biasa untuk mengadaptasi, mengadopsi, berinteraksi dengan pemikiran-pemikiran seperti Yunani dan India, China dan lainnya di masa lalu. Seperti dijelaskan Islahi sebagaimana dikutip oleh Hoetoro $(2007$; 40-52), bahwa sebenarnya ketika misalnya para cendekiawan Muslim mengadopsi pemikiran Yunani tidak kemudian bercorak Yunani, tetapi yang terjadi adalah terbangunnya tradisi keilmuan yang khas Muslim. Hal yang sama juga harusnya dilakukan ketika Islam berinteraksi dengan Ekonomi/Bisnis/Akuntansi Barat/ 
Kristen dan atau Neoliberal saat ini, baik itu substansi keilmuan yang dibawanya (aksioma, lemma, proposisi, hipotesis, model, teori-teori, konsep, prinsip-prinsip, standar, praktik), maupun pendekatan paradigmatikyang melekat padanya (Positivistik maupun pencabangan paradigmatik Interpretif, Kritis, Posmodernisme, bahkan yang paling mutakhir saat ini, yaitu seperti Feminisme atau bahkan Spiritualitas ala Capra atau Zonah dan Marshall misalnya) ${ }^{5}$. Tawhid adalah kata kunci filter utama, dan maqashid syariah adalah implementasi teknikalnya,sehingga semua substansi keilmuan dan paradigma tidak boleh lepas dari proses "tazkiyah". Menjadi benarlah yang dikatakan oleh Faruqi (1987: 15) ketika menyodorkan ide Islamisasi Pengetahuan yang fenomenal itu:

The task of integration is not an eclectic mixing of classical Islamic and modern Western knowledge, but rather a systematic orientation and restructuring of the entire field of human knowledge in accordance with a new set of criteria and categories, derived from, and based on, the Islamic worldview"

Kajian Non Positivisticdan Ushul Fiqhdalam Constructive Mapping dilakukan sebagai berikut. Pertama, Pendekatan Tarikh, Sirah atau metodologi baru sejarah seperti pendekatan Genealogis merupakan agenda keseimbangan informasi historis-prediktifproyektif. Memotret ulang sejarah, masa kini dan masa depan ekonomi Islam bukan dalam kronologi waktu dan tokoh saja. Sejarah Ekonomi Islam harus bisa menempatkan dirinya dalam ruang kebersahajaan sebagai wacana dan aksi yang memang didorong secara sinergis para tokoh, penggiat langsung, dan masyarakat. Kedua, Pendekatan Social Structure, Tafsir, Ta'wil atau lainnya merupakan positioning approach untuk menemukan struktur kelembagaan kemasyarakatan, sepertiMasyarakat Desa-Kota, Lembaga Formal-Informal, Masyarakat Terdidik-Pekerja, Masyarakat Muslim-Nonmuslim, Masyarakat Aktivis - Grass Root, PetaniEnterpreneur-Birokasi dan lain-lain. Ketiga, Pendekatan Burhani atau Fenomenologis untuk menemukan metafisika masyarakat.

5 Untuk pendekatan paradigmatic Barat/Konvensional di ranah organisasi misalnya Burell dan Morgan (1979); di ranah akuntansi misalnya Chua (1986)
Menemukan metafisika berpikir dan batin pemetaan kelembagaan dan masyarakat dari poststructural approach. Membuat database dasar berpikir dan beraktivitas struktur kelembagaan dan masyarakat sesuai dengan latar belakang budaya dan interaksi sosial kekinian. Keempat, Pendekatan Antropologis untuk melihat realitas keseharian. Meneliti lebih jauh bagaimana metafisika berpikir dan batin masyarakat kemudian membentuk aktivitas sosial-ekonomi dalam koridor everyday life. Menjembatani kebijakan makro dan mikro ekonomi islam, mendekatkannya pada ruang antropologis masyarakat.

Berdasarkan Non-Positivistic dan Ushul Fiqh Approach di atas diperlukan sinergi dengan PositivisticApproach, yaitu Sinergi Emansipasi (Emancipation Approach). Sinergi atas analisis kebijakanpositivism, ushul fiqh dan nonpositivism dalam bentuk kerangka General Idea dan Practical Content. Sinergi Ide dan Praktik untuk membuat kerangka kebijakan Aksi yang konkrit. Kebijakan Aksi Ekonomi Islam ini tetap memberikan keseimbangan informasi dan studi berbasis empiris kuantitatif dan kualitatif sekaligus, empiris pikiran dan batin sekaligus, semua tetap dalam kerangka normatif Tawhid, sebagai paradigma utamanya.

Makna terpenting dari makrifat berekonomi Indonesia saat ini, sekarang ini, sama seperti proklamasi menuju kemerdekaan yang bukan lagi hanya mengenang dan merefleksikan pembebasan diri para pejuang kemerdekaan untuk benar-benar bebas dari penindasan militer asing. Makna makrifat menuju proklamasi berekonomi adalah menjalankan Hijrah menuju Fitrah Manusia Indonesia, Fitrah Rakyat Indonesia, Fitrah Negara Tercinta ini dari penjajahanEkonomi yang tengah melanda negara ini.

Makrifat Proklamasi Berekonomi untuk membebaskan diri dari Penjajahan Ekonomi berjubah Neoliberalisme melalui Regulasi, Liberalisasi dan Perdagangan Bebas. Pertama, Proklamasi Dekonstruksi Regulasi dengan cara melakukan revisi besar-besaran seluruh Undang-Undang serta Peraturan turunannya dari cengkeraman Kebijakan Ekonomi Pro MNC's (Multi National Company's). Kedua, Proklamasi Dekonstruksi Liberalisasi dengan cara melakukan revisi besar-besaran seluruh agenda penjualan aset dan perusahaan nasional maupun BUMN dari pemindahan saham kepada perusahaan maupun negara asing. Paling penting lagi adalah kemandirian berekonomi, salah satu caranya 
adalah nasionalisasi perusahaan-perusahaan demi terbentuknya kemandirian ekonomi nasional. Ketiga, Proklamasi Dekonstruksi Perdagangan Bebas dengan cara mengangkat potensi ekonomi rakyat lewat pemberdayaan dan bukannya memperdayai ekonomi rakyat sampai siap menjadi pelaku ekonomi di negeri sendiri dan mampu melakukan persaingan secara global. Tekanan pentingnya adalah pemerintah segera melakukan kebijakan komprehensif berdasarkan kepentingan ekonomi rakyat. Inilah makna dari Proklamasi Berekonomi dengan Cinta, Ekonomi penuh cinta atas rakyat Indonesia.

Agenda beberapa tahun ke depan adalah merancang pemberdayaan mikro tanpa meninggalkan pengembangan makro ekonomi. Artinya, saatnya memikirkan lebih konkrit mekanisme yang menyentuh langsung pada sektor riil. Beberapa hal dapat dilakukan:

1. Menemukan formulasi mikro ekonomi berasaskan mashlaha untuk semua. Mekanisme zakat, infaq dan shadaqah bukan hanya sebagai bentuk kewajiban, tetapi perludielaborasi lebih jauh sebagai inti pendekatan mikro yang berdampak pada ekonomi makro.

2. Menemukan dari bawah mekanisme bertani, bertambang, berdagang, berinvestasi, produksi dan melakukan pemasaran bagi ekonomi rakyat secara luas dan berkeadilan.

3. Mengembangkan akhlak bisnis ekonomi rakyat berbasis spiritualitas Islam itu sendiri.

4. Menggali dan mengangkat kearifan 1okal dalam berekonomi. Konsekuensinya adalah menelusuri mekanisme manajemen, administrasi dan keuangan/akuntansi ekonomi rakyat sesuai realitas Ke-Indonesia-an tanpa meninggalkan batasan syari'ah.

5. Mensinergikan mikro dan makro ekonomi atas dasar kepentingan ekonomi, sosial, lingkungan dalam bingkai ketundukan untuk mewujudkan mashalah untuk semua

6. Pengembangan teknis, yaitu alternatif konsep pembiayaan, seperti salaf atau qardh yang memang secara tradisional fiqh-nya lebih dekat dekat sistem pinjaman/pembiayaan

7. Sistem muzara'ah dan musaqah juga hanya dilihat untuk pertanian. Perlu pengembangan berbasis sistem tersebut karena lebih dekat dengan sistem investasi-produktif, daripada sistem musyarakah atau mudharabah yang lebih dekat dengan investasi-perdagangan

\section{CATATAN AKHIR}

Rancangan Riset Ekonomi Islam sedemikian jauh, sampai detik ini dan sampai ke depan, tidak pernah berhenti berproses berjalin berkelindan seperti zikirnya tiaptiap insan Muslim, tiap-tiap hari, tiap-tiap kapanpun mengikuti pola peradaban kemanapun ia berjalan. Tak lekangnya pergulatan akademis itu pulalah obor dinamisme ilmiah Ekonomi Islam di tengah pergulatan peradaban yang terus bergulir tak selesai, kecuali Allah menghendakinya sebagai ujung segalanya. Diskursus filosofis, paradigmatic, teoritik, sampai kemashalahatan praktik adalah ruang bagi pencerahan setiap abdi Allah dalam mengemban amanah kekhalifahannya. Manusia tercerahkan, Insan Ulil Albab-lah yang dapat mengetahui "tandatanda" dan Ekonomi Islam hanya akan terbit menyinari Semesta Tuhan, hanya karena sang insan selalu berinteraksi menuju kebaikan semuanya. Insya Allah. Be the light that you are.

\section{DAFTAR RUJUKAN}

Al-Faruqi, I.R. 1987. Islamization of Knowledge: General Principles and Workplan. Herndon, Virginia USA.

Al-Faruqi, I.R. 1998. Al-Tawhid: Its Implication for Thought and Life.Fourth Printing.IIIT. Herndon Virginia USA.

Bank Indonesia.2012. Statistik Perbankan Syariah September.

Capra, F. 1981. The Turning Point. Berkeley.

Capra, F. 1996. The Web of Life: A New Scientific Understanding of Living Systems. Anchor Books. United States of America.

Capra, F. 1999. The Tao of Physics. $4^{\text {th }}$ Edition. Terjemahan. 2005. Jalasutra. Yogyakarta. Capra, Fritjof. 2003. The Hidden Connections: A Science for Sustainable Living. Flamingo. Great Britain.

Chapra, M.U. 2000. Islam dan Tantangan Ekonomi. Terjemaham GIP Jakarta.

Choudhury, M.A. 2005. Islamic Economics and Finance : Where Do We Stand? Islamic Economics and Banking in the $21^{\text {st }}$ Century. $6^{\text {th }}$ International Confer- 
ence onIslamic Economics and Finance. Jakarta-Indonesia, November 21-24.

Dawwabah, A.M. 2006. Meneladani Keunggulan Bisnis Rasulullah:Membumikan Semangat Etika Bisnis Rasulullah. Terjemahan Pustaka Nuun Semarang.

Dua, M. 2008. Filsafat Ekonomi: Upaya Mencari Kesejahteraan Bersama. Penerbit Kanisius Jogjakarta.

Furqani, H. dan M.A. Haneef. 2011. Methodology of Islamic Economics: Typology of Current Practices, Evaluation and Way Forward. Proceeding 8th International Conference on Islamic Economics and Finance. Qatar.

Friedman, M. 1953/1966. The Methodology of Positive Economics. Essays in Positive Economics. University of Chicago Press.pp 3-16, 30-43.

Ghazali, A. Dan S. Omar. 1989. Readings in the Concept and Methodology of IslamicEconomics. Pelanduk Publication. Malaysia

Hatta, M. 1947. Penundjuk Bagi Rakjat dalam Hal Ekonomi: Teori dan Praktek. Penerbit Kebangsaan Pustaka Rakjat. Jakarta

Hoetoro, A. 2007. Ekonomi Islam: Pengantar Analisis Kesejarahan dan Metodologi. BPFE-Unibraw dan Bayumedia Publishing.

Jazuli, A.S. 2006. Hijrah dalam Pandangan Al Qur'an. Terjemahan GIP Jakarta. Karim, Adiwarman Azwar. 2004. Sejarah Pemikiran Ekonomi Islam. Edisi Kedua. Penerbit Rajawali Jakarta.

Lawson, T. 2002. Economics and Reality. Routledge, Taylor\& Francis Group. London and New York.

Mulawarman, A. D. 2006. Menyibak Akuntansi Syariah. Penerbit Kreasi Wacana. Jogjakarta.

Mulawarman, A. D. 2007. Target 5\% Bank Syariah: Untuk Mashlaha? Makalah SeminarInteraktif "Shari'ah Weekend". LEM FE-UII dan KOPMA FE UII, Jogjakarta, 13Desember.

Mulawarman, A. D. 2010. Masa Depan Ekonomi Islam. Kuliah Tamu Ekonomi Is- lam, STAIN Kediri, Jawa Timur. 11 Oktober.

Mulawarman, A. D. 2012. Perkembangan dan Tantangan Perbankan Syariah dalam Bingkai Ekonomi Kerakyatan. Orasi Ilmiah Wisuda Sarjana Universitas Widyagama Mahakam, Samarinda, Kalimantan Timur. 15 Desember.

Muqorrobin, M. 2008. Journey of Islamic Economics in the Modern World. The $7^{\text {th }}$ International Conference in Islamic Economics. King Abdul Aziz University. April.

Nasr, S.H. 2003. Antara Tuhan, Manusia dan Alam: Jembatan Filosofis danReligius Menuju Puncak Spiritual. Terjemahan Ircisod. Jogjakarta.

O'Hara, P.A. 2002. The Contemporary Relevance of the Critical Economic Systems Approach to Political Economy in the Tradition of Marx, Veblen, Keynes and Schumpeter. International Journal of Applied Economics and Econometrics. Jan-Mar Vol. 10 No. 1 pp 126-150.

Ormerod.P. 1994. The Death of Economics. London. Faber and Faber.

Safi, L. 1996. The Foundation of knowledge: A comparative study in Islamic and Western methods of inquiry. Malaysia: IIUM \& IIIT.

Schumacher, E.F. 1981. Keluar Dari Kemelut: Sebuah Peta Pemikiran Baru. Terjemahan LP3ES. Jakarta.

Sen, A.On Ethics and Economics, Oxford, Basil Blackwell, 1987.

Shihab, Q. 2000. Wawasan Al Qur'an: Tafsir Maudhu'i atas Pelbagai Persoalan Ummat. Penerbit Mizan Bandung.

Soedjatmoko. 1986. Dimensi Manusia Dalam Pembangunan. LP3ES. Jakarta.

Wainwright, S.P. 2000. For Bourdieu in Realist Social Science.Cambridge RealistWorkshop 10th Anniversary Reunion Conference.Cambridge.

Zohar, D. dan I. Marshall. 2005. Spiritual Capital: Memberdayakan SQ di Dunia Bisnis. Terjemahan. Mizan Bandung. 